Теслюк Софія, кандидат економічних наук,

Волинський національний університет імені Лесі Українки, кафедра фінансів, м. Луцьк; ORCID ID: 0000-0003-2364-0257 e-mail: Tesliuk.Sofiia@vnu.edu.ua

Матвійчук Наталія, кандидат економічних наук, доцент, Волинський національний університет імені Лесі Українки, кафедра фінансів, м. Луцьк; ORCID ID: 0000-0001-7168-4073 e-mail: matviichuk.nataliia@vnu.edu.ua

Деркач Оксана, здобувач вищої освіти спеціальності «Фінанси, банківська справа та страхування», Волинський національний університет імені Лесі Українки, м. Луцьк, e-mail: oksana.derkach25@gmail.com

Корх Наталія, здобувач вищої освіти спеціальності «Фінанси, банківська справа та страхування», Волинський національний університет імені Лесі Українки,

https://doi.org/10.29038/2786-4618-2021-03-61-71

м. Луцьк, e-mail: Korkh.Nataliya2018@vnu.edu.ua

\title{
НЕОБАНКИ: СУТНІСТЬ ТА ПЕРСПЕКТИВИ РОЗВИТКУ В УКРАЇНІ
}

У статті досліджено особливості функціонування, а також перспективи розвитку необанків в Україні та світі. В роботі представлено теоретичні підходи до визначення сутності необанків, а також характеристику законодавчого регулювання їх діяльності в Україні. Узагальнено особливості діяльності та тенденції розвитку найбільших європейських необанків. Здійснено аналіз впливу сучасних тенденцій в банківській сфері на скорочення структурних підрозділів традиційних банків, готовності населення до нового виду банківського обслуговування - обслуговування в необанках. Досліджено динаміку клієнтської бази найбільших традиційних банків та найпопулярнішого необанку в Україні - Монобанку.

Загалом проведене дослідження дало змогу визначити переваги та недоліки діяльності необанків, а також перспективи їх розвитку в Україні.

Ключові слова: банківська система, необанки, віртуальний банк, інновації, монобанк, розвиток.

Теслюк София, кандидат экономических наук, Волынский национальный университет имени Леси Украинки, кафедра финансов, г. Луцк

Матвийчук Наталия, кандидат экономических наук, доцент, Волынский национальный университет имени Леси Украинки, кафедра финансов, г. Луцк

Деркач Оксана, 
соискатель высшего образования специальности «Финансы, банковское дело и страхование», Волынский национальный университет имени Леси Украинки, г. Луцк

Корх Наталья, соискатель высшего образования специальности «Финансы, банковское дело и страхование», Волынский национальный университет имени Леси Украинки,

\section{НЕОБАНКИ: СУЩНОСТЬ И ПЕРСПЕКТИВЫ РАЗВИТИЯ В УКРАИНЕ} г. Луцк

В статье исследовано особенности функционирование, а также перпективы развития необанков в Украине и мире. В работе представлены теоретичиские подходы к определению сощности необанков, а также характеристику законодательного регулирования их деятельности в Украине. Обобщены особенности деятельности и тенденции развития наибольших европейских необанков. Осуществлен аналіз влияния современных тенденций в банковской сфере на сокращение структурних подразделений традиционных банков, готовности населения к новому виду банковского обслуживания - обслуживанию в необанках. Исследована динамика клиентской базы наибольших традиционных банков и самого популярного необанка в Украине Монобанка.

В целом проведенное исследование дало возможность определить преимущества и недостатки деятельности необанков, а также перспективы их развития в Украине.

Ключевые слова: банковская система, необанки, виртуальный банк, инновации, монобанк, развитие.

Tesliuk Sofiia, PhD in Economics, Lesya Ukrainka Volyn National University, Department of Finance, Lutsk

Nataliia Matviichuk, PhD in Economics, Associate Professor, Lesya Ukrainka Volyn National University, Department of Finance, Lutsk

Korh Natalia, Applicant for the speciality «Finance, Banking and Insurance», Lesya Ukrainka Volyn National University, Lutsk

\section{Derkach Oksana,} Applicant for the speciality «Finance, Banking and Insurance», Lesya Ukrainka Volyn National University, Lutsk

\section{NEOBANKS: THE ESSENCE AND PROSPECTS OF DEVELOPMENT IN UKRAINE}

The modern world is very dynamic, changeable and unpredictable. According to recent events in the world, all spheres of life are undergoing changes, including the financial system of countries in which the main role is played by banks. Over the last few decades, the banking system has undergone dramatic changes. The development of the banking services market is impossible without the introduction of innovative technologies and products to improve customer service. Banking institutions that do not have automated software services will not be able to compete with technically equipped banks. That is why in the modern world there is a need for new, innovative types of banking institutions - neobanks. 
The article examines the peculiarities of the formation and functioning of neobanks in Ukraine and the world, as well as identifies the prospects for their further development. The paper presents theoretical approaches to defining the essence of neobanks and the proposed author's definition, according to which neobank is an innovative bank that is available to customers through a mobile application, has no classic banking dapartment and interact with customer through Internet platforms.

Peculiarities of activity and tendencies of development of the largest European neobanks are generalized. An analysis of the impact of current trends in the banking sector on the reduction of structural units of traditional banks, the readiness of the population for a new type of banking services - services in non-banks. The dynamic of the client base of the largest traditional banks and the most popular neobank in Ukraine - Monobank has been studied. According to a study by Monobank, over the past six years it has grown its customer base more than 6 times, which is significantly higher than that of the largest traditional banks.

The article mentions an important condition for the development of non-banks in Ukraine - the improvement of the regulatory framework that would determine the legal status of such institutions, as well as the conditions for licensing and regulation of their activities.

In general, the study made it possible to identify the advantages and disadvantages of neobanks, as well as prospects for their development in Ukraine.

Key words: banking system, neobanks, virtual bank, innovations, monobank, development.

Постановка проблеми та ії значення. Останніми роками все більше використовуються інформаційні сучасні технології в наданні послуг фінансової сфери, банки перестають бути лише банками в традиційному розумінні та виходять за межі фінансової галузі. У зв'язку з доступністю до Інтернету та соціальних мереж, появою онлайн-магазинів, мобільних додатків та смартфонів, виникли інноваційні банки, так звані «необанки», які є більш зручними та швидкими ніж традиційні банки. За кордоном поняття необанкінгу вже стало звичним, проте Україна лише починає розвивати такий вид бізнесу. Враховуючи, що українське законодавство ще не регламентує діяльність таких установ, в сучасних умовах розвитку банківського сектору ця тема $є$ особливо актуальною.

Аналіз останніх досліджень і публікацій. Сучасним тенденціям розвитку та функціонування необанків в Україні та світі присвячені праці таких авторів, як: Р. Беззуб, Л. Городянська [10,13], Л. Гут [11] С. Гошал, Д. Дранове, М. Міллер, Х. Мінскі, Ф. Мишкін, Р. Мертон, Дж. Скан, Дж. Дікерс, К. Скінер, Т. Калашнікова, Ю. Савченко. Більшість вчених вважають, що необанки досить швидко займуть достойне місце на ринку банківських послуг, але досі існують проблеми, які не дозволяють їм запрацювати на повну потужність. Тому вважаємо за потрібне детальніше дослідити питання сутності необанку, особливостей функціонування необанків у зарубіжних країнах, переваги та недоліки ї діяльності. Актуальним залишається дослідження перспектив розвитку необанків в Україні, а також нормативно-правове забезпечення їх діяльності.

Мета і завдання статті. Метою статті є дослідження стану банківської системи України для визначення перспектив розвитку віртуальних банків (необанків) в Україні.

Виклад основного матеріалу та обгрунтування отриманих результатів дослідження. Поняття «необанк» часто ототожнюють з термінами «віртуальний», «мобільний банк», «інтернетбанк», «цифровий банк», «банк-челенджер» та «директ-банки». Однак всі ці терміни мають на увазі лише одне - банк без відділень.

Багато вчених дані поняття трактують по-різному. Зокрема, Говорушко Т., Ситник І., Немченко T. використовують визначення «віртуальний банк» і вважають, що «віртуальний банк - це типовий банк, який більш активно використовує можливості інтернет-банкінгу, ніж інші банки» [1].

Козляченко Е. та Березан А. вживають поняття «необанк» та розглядають його як фінансовокредитну установу, яка проводить різного роду банківські операції, при цьому використовує не офісні відділення, а лише віртуальну мережу і сучасні Інтернет-платформи [2].

Еркес О., Калита О. та Гордієнко Т. вводять таке поняття, як «директ-банк» і тлумачать його так: директ-банк - це банк, що не має мережі філій та пропонує свої послуги віддалено, через Інтернет-банкінг та телефонний банкінг, а також надає доступ до своїх послуг через банкомати, термінали обслуговування, мобільні та інші додатки [3]. 
На нашу думку, необанк - це інноваційний банк, який доступний клієнтам через мобільний додаток, не має класичних банківських відділень та взаємодіє з клієнтами через Інтернет-платформи.

Згідно із ст. 47 Закону України «Про банки і банківську діяльність» [4] і ст. 14 Закону України «Про платіжні системи та переказ грошей» [5] процедура відкриття і ведення поточних рахунків доступна лише класичним банкам. Тому віртуальні банки повинні співпрацювати 3 існуючими комерційними банками і здійснювати свою діяльність на підставі їх ліцензії.

Історія необанків розпочалась ще у Великій Британії, де 1989 р. на ринку фінансових послуг 3'явився перший необанк - First Direct. Даний банк почав працювати без відділень, цілодобово обслуговуючи клієнтів за допомогою колл-центру. На сьогодні First Direct - це підрозділ HSBC Bank.

Станом на 24 грудня 2020 року у світі налічувалося 256 необанків, а ще ряд готується до запуску. Загальний обсяг інвестицій в шість найбільш успішних європейських необанків: N26, Revolut, Monzo, Tandem Bank, Atom Bank, Starling Bank - перевищує \$ 2 млрд. До найбільш відомих можна віднести британські Atom Bank, який був заснований у 2014 році, Tandem Bank (заснований 2013 p.), Monzo Bank (2015 p.), Starling Bank (2014 p.), американський Simple (2009 p.), китайські WeBank (2015 p., перший цифровий банк у Китаї), WYbank (2015 р.), німецькі Fidor Bank (2019 р.) та N26 (2015 p.).

Станом на 2021 рік до ТОП-10 необанків належать такі: Revolut (2015 p.), N26, Monese (2015p.), Starling, Bunq (2012 p.), Monzo Bank, Tinkoff Bank (2006 p.), Точка (2015 p.), Monobank, Chime (2012 p.).

\section{Характеристика найбільших свропейських необанків}

Таблиия 1

\begin{tabular}{|c|c|}
\hline Назва & Тарактеристика \\
\hline Revolut & $\begin{array}{l}\text { Є компанією фінансових технологій у Великобританії, яка обслуговує більше } 12 \\
\text { мільйонів клієнтів більше ніж в } 35 \text { країнах світу, підтримує більше близько } 30 \\
\text { валют, в т.ч. криптовалюту. }\end{array}$ \\
\hline N26 & $\begin{array}{l}\text { Депозити на суму до } 100 \text { тис. євро застраховані Європейською системою } \\
\text { гарантування вкладів. } \\
\text { Кількість користувачів перевищує } 7 \text { мільйонів у } 25 \text { країнах. } \\
\text { Щодня клієнтська база збільшується на } 3 \text { тис. } \\
\text { Банк пропонує великий спектр рішень для інтеграції з IOS, серед них миттєвий } \\
\text { переказ коштів через іМеssage або Siri. } \\
\text { N26 активно працює над штучним інтелектом для аналізу потенційних клієнтів. }\end{array}$ \\
\hline Monese & $\begin{array}{l}\text { Відкриває рахунки для резидентів більш ніж } 30 \text { країн. } \\
\text { Рахунки можна відкрити в EUR, RON, GBP. } \\
\text { Як і в більшості необанків, відкриття рахунку відбувається за кілька годин без } \\
\text { підтвердження місця проживання та кредитної історії. }\end{array}$ \\
\hline Starling & $\begin{array}{l}\text { Обслуговує майже } 1,8 \text { млн рахунків, на яких зберігається майже } 4 \text { млрд фунтів } \\
\text { стерлінгів, однак відкриває рахунки лише резидентам Великої Британії. }\end{array}$ \\
\hline Bunq & $\begin{array}{l}\text { Пропонує безкоштовний рахунок для подорожей, преміум-рахунок за 7,99 євро в } \\
\text { місяць та Premium SuperGreen за 16,99 євро за місяць для фіз.осіб, а також } 2 \text { тарифи } \\
\text { для бізнесу. } \\
\text { Проте карти випускаються тільки в Європі. } \\
\text { У листопаді } 2019 \text { року Вunq випустив металеву карту Green Card, за кожні } \\
\text { витрачені } 100 \text { євро висаджується дерево, які допомагають скорочувати CO2. }\end{array}$ \\
\hline Monzo Bank & $\begin{array}{l}\text { Клієнтська база } 2 \text { млн. осіб. } \\
\text { Клієнти можуть безкоштовно користуватися послугою овердрафту, а на депозити } \\
\text { понад } 1 \text { тис. фунтів стерлінгів додатково нараховується } 1 \% \text {. }\end{array}$ \\
\hline Tinkoff Bank & $\begin{array}{l}\text { Капіталізація групи TCS Group, якій належить Tinkoff, перевищила } 5 \text { млрд. дол.. } \\
\text { Обслуговує більше } 12 \text { млн. клієнтів в Росії. } \\
\text { У } 2020 \text { році став кращим мобільним банком в світі за версією журналу Global }\end{array}$ \\
\hline
\end{tabular}




\begin{tabular}{|l|l|}
\hline & Finance. \\
\hline Tочка & $\begin{array}{l}\text { Нараховує більше 2000 тис. користувачів по Росії. } \\
\text { Міжнародна асоціація бізнес-банкірів SME Banking Club визнала банк для } \\
\text { підприємців Точка кращим онлайн-банком для малого та середнього бізнесу }\end{array}$ \\
\hline Monobank & $\begin{array}{l}\text { У } 2020 \text { р. кількість користувачів зросла до 2,5 млн. } \\
\text { В березні 2020 р. почали випуск карток у Великій Британії під брендом Koto. }\end{array}$ \\
\hline Chime & $\begin{array}{l}\text { Клієнтська база більше 12 млн. осіб. } \\
\text { Можливість отримати } 100 \text { дол. на рахунок без відсотків, якщо раптом не вистачає } \\
\text { коштів для здійснення покупки. Для цього потрібно щомісяця поповнювати } \\
\text { рахунок карти на } 500 \text { дол. США. }\end{array}$ \\
\hline
\end{tabular}

Джерело: сформовано автором на основі [14]

3 наведеного вище списку можна спостерігати, що найбільш сприятливим юридичним середовищем для відкриття установи необанку є Велика Британія. Це пояснюється лояльним ставленням державного регулятора (FCA), мінімальним оподаткуванням, розвинутим ринком персоналу в галузі фінансових технологій, доступом до величезної бази даних про інвесторів, а також можливістю для необанку отримати спеціальну ліцензію та не пропонувати свої послуги на підставі ліцензії традиційного банку.

Вітчизняні банкіри передбачають поступовий перехід від традиційного банкінгу до необанкінгу шляхом зменшення кількості відділень банків та залучення більшості клієнтів до Інтернет-банкінгу. В Україні продовжується тенденція до зменшення кількості банків та їх відділень, що розпочалось у світі ще десятиріччя тому. Коронокриза пришвидшила цей процес, крім того відбувся перехід до віддаленої роботи з клієнтами, посилилися кіберзагрози, суттєво зменшилась роль готівки. Поряд із скороченням кількості банків в Україні на 37,6 \% за аналізований період (2015-2020 рр.), спостерігається стійка тенденція зростання їх чистих активів (табл. 2). Так, на кінець 2020 року вартість чистих активів у порівнянні з 2015 роком зросла на 45,4\%.

Таблиия 2

Стан банківської системи України (2015-2020 рр.)

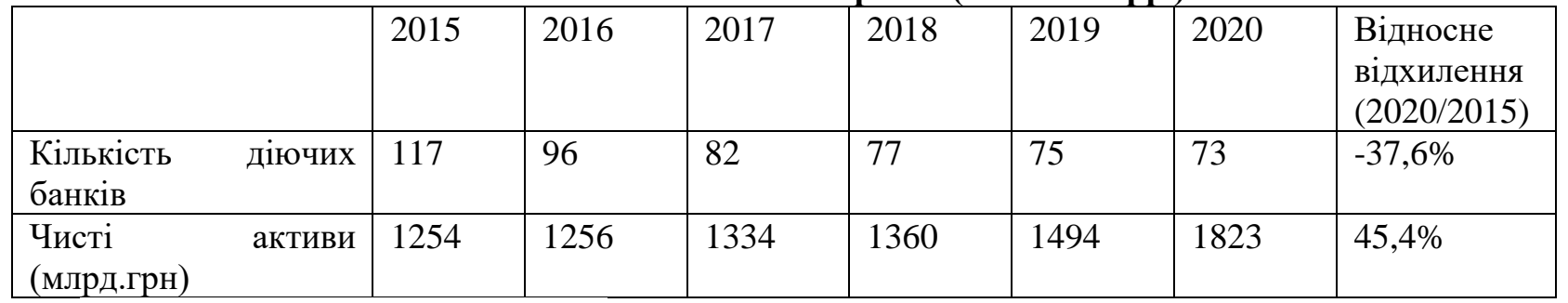

Джерело: створено автором на основі [18]

Найпомітніша тенденція до скорочення відділень спостерігається у АТ Ощадбанк, в якого за період 2018-2021 рр. закрилось 1368 структурних підрозділів, що становило 61 \% від їх кількості у 2018 році (61\%). Приватбанк за аналізований період закрив 526 відділеннь (залишилося 1717), банк Райффайзен закрив 107 відділень (залишилось 396), Укрсиббанк - 53 відділень (залишилось 272). Водночас нові відділення відкрили Укргазбанк -33 (стало 276), А-Банк - 21 (стало 232). За даними інформаційного порталу «Мінфін» загальна кількість відділень на сьогодні становить близько 7 тис, тоді як на піку було майже 23 тис. Основними причинами закриття є: економія, зменшення ринку, діджіталізація банківської галузі, активний розвиток дистанційних каналів обслуговування [19].

Динаміка структурних підрозділів традиційних банків в Україні за 2018-2021 рр.

\begin{tabular}{|l|l|l|l|l|l|}
\hline \multicolumn{1}{|c|}{} & Рік & 2018 & 2020 & 2021 & $\begin{array}{l}\text { Відносне } \\
\text { відхилення } \\
\text { (2021/2018) }\end{array}$ \\
\hline Ощазва & & & & & \\
\hline
\end{tabular}


Економічний часопис Волинського національного університету імені Лесі Украӥнки

\begin{tabular}{|l|l|l|l|l|l|}
\hline ПриватБанк & 2243 & 2021 & 1928 & 1717 & $-23,5 \%$ \\
\hline $\begin{array}{l}\text { Райффайзен } \\
\text { банк }\end{array}$ & 503 & 503 & 496 & 396 & $-21,3 \%$ \\
\hline Укрсиббанк & 325 & 300 & 284 & 272 & $-16,3 \%$ \\
\hline Укргазбанк & 243 & 246 & 250 & 276 & $13,6 \%$ \\
\hline А-БАНК & 211 & 225 & 225 & 232 & $10,0 \%$ \\
\hline
\end{tabular}

Джерело: створено автором на основі [18]

Про готовність населення України до переходу на інший рівень банківського обслуговування обслуговування в необанках- свідчить і зростання кількості користувачів найпопулярнішого інтернет-банкінгу в Україні від Приватбанку «Приват24» (рис.1). Даний сервіс працює з березня 2001 року і був першопрохідцем в сфері інтернет-банкінгу.

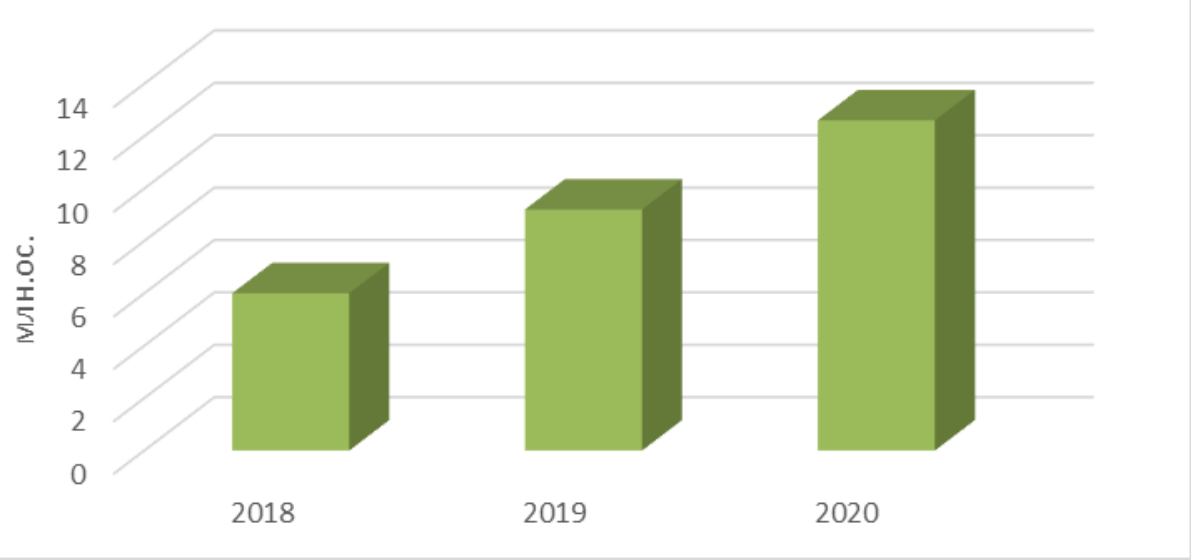

Рис. 1. Кількість користувачів Приват-24 у 2018-2020 p.p.

Джерело: створено автором на основі [16]

3 рис. 1 можна стверджувати, що відбувається підвищення попиту на інноваційні системи обслуговування та безготівкові операції, що є позитивним чинником для розвитку необанків в Україні.

Сьогодні в Україні функціонують7 віртуальних банків: Monobank, Izibank, Sportbank, O.Bank, Neobank, Todobank та «Власний рахунок» (табл. 4).

\section{Характеристика необанків в Україні}

Таблиця 4

\begin{tabular}{|c|c|}
\hline Назва & Характеристика \\
\hline Monobank & $\begin{array}{l}\text { Перший в Україні необанк. } \\
\text { Здійснює свою діяльність на основі банківської ліцензії Універсал Банку, що } \\
\text { входить до групи ТАС. }\end{array}$ \\
\hline Izibank & Працює на платформі АТ ТАСКОМБАНК. \\
\hline Sportbank & $\begin{array}{l}\text { Спільний проєкт IT-компанії Dyvotech i компанії N1. } \\
\text { Здійснює діяльність на базі ліцензії Оксі Банку. } \\
\text { Особливістю є наявність кешбеку до 10\% на купівлю спорт товарів. }\end{array}$ \\
\hline O.Bank & Проєкт Idea Bank, працює на підставі його ліцензії. \\
\hline Neobank & Стартап від Concord Bank. \\
\hline Todobank & $\begin{array}{lllll}\text { Стартап став продовженням мобільного застосунку } & \text { «Megabank } & \text { Online» від } \\
\text { Мегабанку і працює на його ліцензії. } & & & \\
\end{array}$ \\
\hline $\begin{array}{l}\text { «Власний } \\
\text { рахунок» }\end{array}$ & Створений на базі банку «Восток» та Fozzy Group Володимира Костельмана. \\
\hline
\end{tabular}


Варто зазначити, що найпершим у сфері необанкінгу реалізувався проєкт Universal Bank під назвою «Monobank». Монобанк використовує банківську ліцензію Universal Bank та здійснює управління коштами його клієнтів. Лише у 2019 році Universal Bank завдяки цьому проєктові в 15 разів збільшив свій прибуток [23, с. 61]. Банк за рахунок відсутності витрат на інфраструктуру (відділення, банкомати, інкасацію та ін.) зробив набагато вигідніші тарифи для клієнтів та отримав нагороду «Необанк року» від FinAwards 2018 [24]. Monobank дозволяє швидко та просто отримати банківську картку, слідкувати за рухом коштів на своїх рахунках, оплачувати різноманітні послуги та надає багато інших інноваційних послуг.

Порівняємо динаміку клієнтської бази найпопулярнішого серед сучасних банків - Monobank та потужних традиційних банків - Приватбанку, банку ПУМБ, Кредобанку та Укргазбанку.

Динаміка кліснтської бази українських банків за 2018-2020 рр., млн осіб

\begin{tabular}{|l|l|l|l|l|l|}
\hline & 2018 & 2019 & 2020 & $\begin{array}{l}\text { Абсолютний } \\
\text { приріст } \\
(2020 / 2018)\end{array}$ & $\begin{array}{l}\text { Темп } \\
\text { зростання, } \\
\text { \% }\end{array}$ \\
\hline Monobank & 0,5 & 1,7 & 3 & 2,5 & 600 \\
\hline Приватбанк & 22 & 17,2 & 17,8 & $-4,2$ & 80,9 \\
\hline ПУМБ & 1,6 & 2 & 2,2 & 0,6 & 137,5 \\
\hline Кредобанк & 0,5 & 0,55 & 0,6 & 0,1 & 120 \\
\hline Укргазбанк & 1,3 & 2,1 & 2,4 & 1,1 & 184,6 \\
\hline
\end{tabular}

Джерело: створено автором на основі [15;16;17;20;21]

3 табл. 5 можемо побачити, що темпи зростання клієнтів Monobank значно перевищують темпи зростання клієнтів усіх банків із зазначеної вибірки. 32018 р. по 2020 p. у Monobank темп зростання склав $600 \%$, в той час, як в Приватбанку всього 80,9\%, в банку ПУМБ - 137,5\%, в Кредобанку $120 \%$, а в Укргазбанку - 184,6\%. Окрім того, $85 \%$ нових клієнтів Monobank приходять із «ПриватБанку», 7 \% - із «Ощадбанку».

Проект Monobank завдячує своєму стрімкому зростанню таким чинникам:

1. свідомо запущені низькі тарифи (пільговий період не 55 днів, а 62, ліпші умови 3 кредитного ліміту тощо);

2. ефективна реклама, в тому числі таргетована; Взагалі, залучення одного клієнта обходиться банкові до 10 доларів [23, с. 62].

3. орієнтованість на клієнтів (60\% нових користувачів monobank приходять за рекомендацією друзів, а не завдяки платному залученню);

4. «тонкий шар гумору» (стікери з котом, якого звуть monokit чи QR-кіт);

5. зручний кешбек витрат (повернення частини коштів, які витрачені на покупки або розваги)

6. оплата комунальних послуг без комісії;

7. динамічний CVC2 код для захисту від шахраїв;

8. спільна оплата рахунку;

9. вбудовані ігри $[23,24]$;

10. зручний сервіс підтримки не лише Кол- центрів, а й Telegram, Viber, Facebook тощо. Monobank $\epsilon$ новатором на ринку банківських послух. Зокрема він першим презентував нову функцію безготівкового розрахунку в ресторанах - Shake to Рау. Завдяки ій можна сплатити рахунок у закладах громадського харчування без терміналу, офіціанта та паперового рахунку. Відвідувачу потрібно відсканувати QR-код або ввести номер столика в застосунку monobank, після чого Shake to Рау отримає рахунок із програмного забезпечення закладу. 
Таблиия 6

Порівняння відсоткових ставок по депозитах та кредитах, станом на 01.01.2021 p.

\begin{tabular}{|l|l|l|l|}
\hline Станом на 01.01.2021 p. & Monobank & Приватбанк & ПУМБ \\
\hline Ставка по депозиту, \% & $10 \%$ & $7 \%$ & $6,5 \%$ \\
\hline Ставка по кредиту, \% & $37,2 \%$ & $42,00 \%$ & $47,88 \%$ \\
\hline
\end{tabular}

Джерело: створено автором на основі $[13,14,15]$

Аналізуючи дані табл. 6, можна спостерігати, що Monobank пропонує кращі умови по залученню коштів та наданню кредитів своїм користувачам ніж його конкуренти. Нижчі ставки по кредитах пояснюються відсутністю в необанку витрат на відділення, інфраструктуру, яку потрібно постійно підтримувати. Прибуток Monobank формується в основному з міжбанківської комісії, так званого інтерчейнджу. Більшу частину прибутку з цієї комісії повертають клієнтам у вигляді кешбека $[23$, с. 70$]$. Таким чином, ми бачимо очевидні перспективи для розвитку Monobank.

Станом на 1.09.2020 p. Monobank зайняв третє місце за кількістю активних карток. До трійки лідерів по активних банківських картка входять: Приватбанк, Ощадбанк та Universal Bank (власних карток цей банк випустив небагато - декілька тисяч, абсолюна більшість - картки Monobank) [22] (рис. 2).

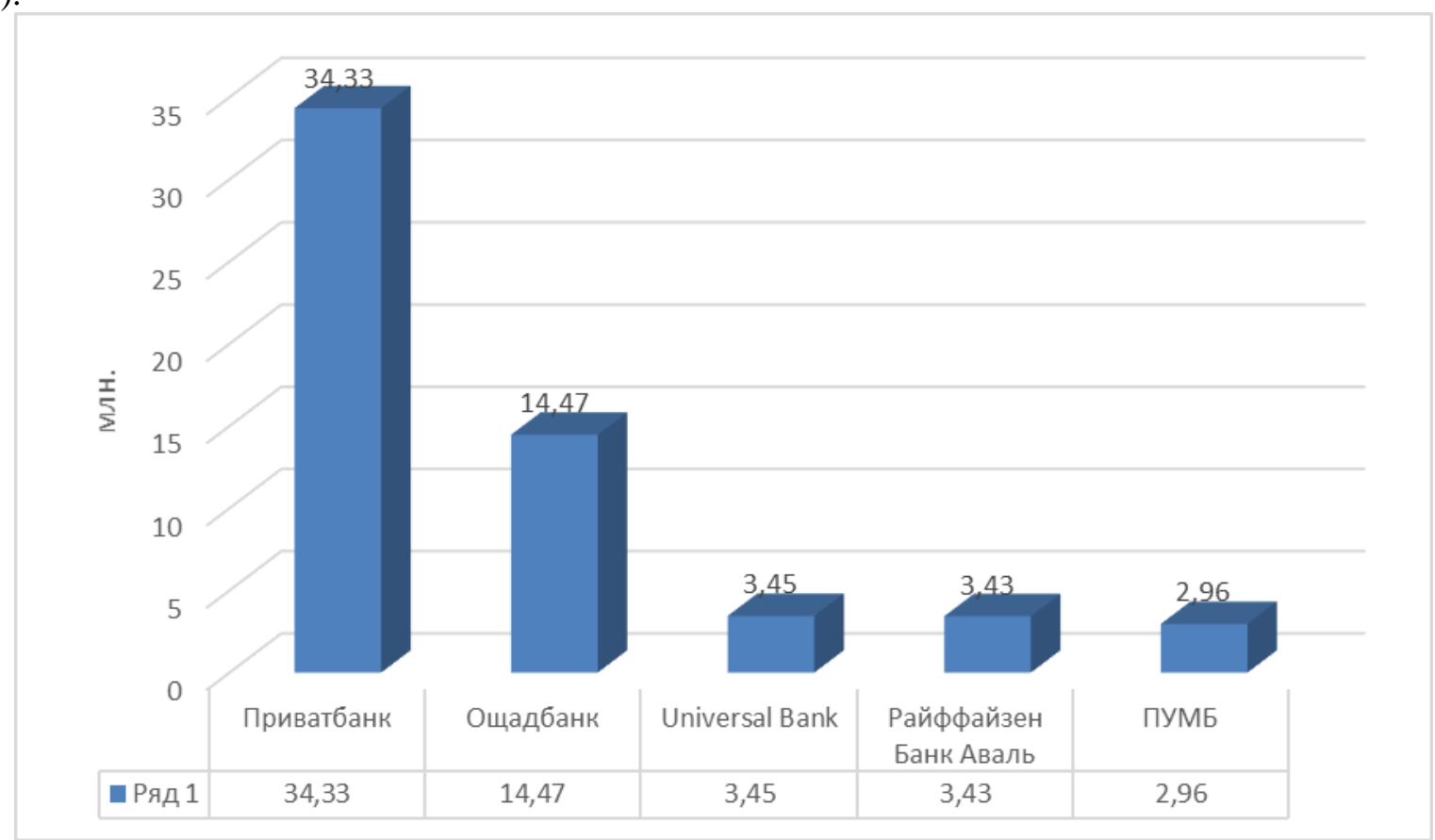

Рис. 2. Кількість активних банківських карток найбільиих банків України Джерело: створено автором на основі [16; 17]

До переваг необанків перед класичними банками для клієнтів даних послуг можна віднести:

○ спрощення процедури реалізації фінансових послуг, відсутність паперового документообігу;

○ застосування нових інструментів, таких як: Р2Р-кредитування, краудфандингові платформи, фінансові роботи-консультанти, криптовалюта;

○ економія часу та зручність для клієнтів;

○ цілодобовий доступ до широкого спектру послуг;

○ нижча вартість комісії за обслуговування, ніж у відділеннях;

○ можливість постійного доступу та контролю за рахунками;

○ вищі процентні ставки по депозитах та вигідні умови кредитування;

○ обслуговування конфліктних клієнтів за допомогою беземоційності та ввічливості роботівконсультантів; 
○ швидкість виконання транзакцій та можливість встановлення регулярних автоматичних платежів;

○ можливість зняття та внесення готівки у будь-якому банкоматі, який приймає Visa та MasterCard по всьому світі без комісій $[9 ; 10 ; 11 ; 12]$.

Однак, окрім переваг, також $є$ і недоліки, які стримують темпи розвитку необанків. Серед них можна виділити наступні:

- витрати на створення і просування додатків та різних програм, сайтів, необхідних для обслуговування клієнтів;

- значні витрати на розробку надійного захисту від кіберзлочинців і вірусів;

- при проблемі на сервері робота з рахунками і документами може зупинитися на невизначений час;

- недовіра значної частини населення до необанків через низьку фінансову грамотність;

- потреба необанку конкурувати не тільки 3 класичними банками, а із такими компаніями, як Google, Apple, WeChatтa Uber, що мають доступ до значної бази даних клієнтів та пропонують їм асортимент фінансових інструментів [13].

На нашу думку, важливою умовою для розвитку необанків в Україні є вдосконалення нормативно-правової бази, яка б визначила правовий статус таких установ, а також умови щодо ліцензування та регулювання їхньої діяльності. Наявність відповідного законодавства дасть змогу ефективно впроваджувати інновації у сфері банківського обслуговування.

Висновки і перспективи подальших досліджень. Отже, сучасний банківський сектор розвивається швидкими темпами. Необанк - це банк сучасності, який впроваджується в наше життя, складаючи конкуренцію класичним банкам. Але для повного переходу населення до таких банків необхідно не тільки замінити відділення на онлайн-платформи, а й забезпечити високий рівень довіри населення, підвищити фінансову грамотність населення, налагодити роботу безперебійного технологічного обладнання, а також розробити відповідну нормативно-правову базу, порядок i умови ліцензування діяльності необанків.

\section{Джерела та література}

1. Говорушко Т., Ситник I., Немченко Т. Загрози і небезпеки розвитку інтернет-банкінгу в Україні. Формування ринкових відносин в Україні. 2013. № 2. C. 74-78. URL: http://nbuv. gov. ua/UJRN/frvu_2013_2_17.

2. Козляченко Е., Березан А. Перспективи розвитку віртуальних банків (необанків) в Україні. Фінансові дослідження. 2019. №2 (7). URL: https://fr.stu.cn.ua/tmppdf/219.pdf

3. Еркес О., Калита О., Гордієнко Т. Потенціал цифрового розвитку банків України. Науковий вісник Ужгородського національного університету. 2019. Випуск 28, частина 1. C.108-114. URL: http://www.visnykeconom.uzhnu.uz.ua/archive/28_1_2019ua/20.pdf

4. Про банки i банківську діяльність. Закон України від 07.12.2000 № 2121-III. URL: https://zakon.rada.gov.ua/laws/show/2121-14\#Text (дата звернення: 14.09.2021)

5. Про платіжні системи та переказ коштів в Україні. Закон України від 05.04.2001 № 2346-III. URL: https://zakon.rada.gov.ua/laws/show/2346-14\#Text (дата звернення: 14.09.2021)

6. Українські необанки: ключові гравці й потенційні ніші для розвитку. Електронна комерція та логістика. 2021. URL: https://elnews.com.ua/uk/ukrayinski-neobanky-klyuchovi-gravczi-j-potenczijni-nishi-dlyarozvytku/.

7. Скільки необанків необхідно Україні? URL: https://minfin.com.ua/ua/credits/articles/skolko-neobankovnuzhno-ukraine/

8. Закон України «Про фінансові послуги та регулювання ринків фінансових послуг» URL: https://zakon.rada.gov.ua/laws/show/2664-14\#Text

9. Бахарєва Я.В. Мобільний банкінг як перспективний напрям розвитку банківських інформаційних систем. Агросвіт. 11 червня 2018. URL: http://www.agrosvit.info/pdf/11_2018.pdf (дата звернення: 10.04.2020).

10. Городянська Л.В. Особливості функціонування необанків. Фінансово-кредитні системи в умовах зміни ділових циклів : Міжн. наук.-практ. Інтернет-конф., Київ, 15 травня 2019 р. С. 141-143. 
11. Гут Л.В. Необанки: зарубіжний та вітчизняний досвід функціонування. Фінансово-кредитні системи в умовах зміни ділових циклів : Міжн. наук.-практ. Інтернет-конф., Київ, 15 травня 2019 р. С. 143-145.

12. Озерчук O.B. On-line банки: зарубіжний досвід. Фінансово-кредитні системи в умовах зміни ділових циклів : Міжн. наук.-практ. Інтернет-конф. Київ, 15 травня 2019 р. С. 147-149.

13. Городянська Л. В. Особливості функціонування необанків. Фінансово-кредитні системи в умовах зміни ділових циклів: Міжнар. наук.-практ. Інтернет-конф. (Київ, 15 травня 2019 р.). Київ, 2015. С. 141-143.

14. ТОП-10 необанков в 2021 году. URL: https://www.universepay.eu/ru/blog/top-10-neobankov-v-2021-godu

15. Офіційний сайт Monobank. URL: https://www.monobank.ua/2020?lang=uk

16. Офіційний сайт Приватбанк. URL: https://privatbank.ua/about

17. Офіційний сайт ПУМБ. URL: https://www.pumb.ua/

18. Офіційний сайт НБУ. URL: https://bank.gov.ua/

19. Офіційний сайт Мінфін. URL: https://minfin.com.ua/ua/banks/

20. Офіційний сайт Кредобанк. URL: https://kredobank.com.ua/

21. Офіційний сайт Укргазбанк. URL: https://www.ukrgasbank.com/

22. Monobank стал третьим по количеству карт, впереди только - «ПриватБанк» и «Ощадбанк». URL: monobank стал третьим по количеству карт, впереди только — «ПриватБанк» и «Ощадбанк» - AIN.UA

23. Ворона. Т. Дмитро Дубілет. Бізнес на здоровому глузді. 50 ідей, як домогтися свого. Київ. Форс Україна. 2020. 256 с.

24. Матвійчук Н. М., Теслюк С. А. Основні тенденції розвитку банківських інновацій в Україні. Економічний часопис Волинського національного університету імені Лесі Українки. Випуск Том 1 № 25 , 2021. c. 79-87. https://doi.org/10.29038/2411-4014-2021-01-79-87

\section{References}

1. Govorushko T., Sytnyk I., Nemchenko T. (2013). Zagrozy i nebezpeky rozvytku internet-bankingu v Ukraini. [Threats and dangers of Internet banking development in Ukraine]. Formuvannya rynkovyx vidnosyn $v$ UkrayiniFormation of market relations in Ukraine, 2, 74-78. Retrieved from: http://nbuv. gov. ua/UJRN/frvu_2013_2_17. [in Ukrainian].

2. Kozlyachenko E., Berezan A. (2019). Perspektyvy rozvytku virtualnyx bankiv (neobankiv) v Ukraini. [Prospects for the development of virtual banks (neobanks) in Ukraine] Finansovi doslidzhennya - Financial research, 2 (7). Retrieved from: https://fr.stu.cn.ua/tmppdf/219.pdf [in Ukrainian].

3. Erkes O., Kalyta O., Gordiyenko T. (2019). Potencial cyfrovogo rozvytku bankiv Ukrainy. [The potencial of digital development of Ukrainian banks]. Naukovyj visnyk Uzhgorodskogo nacionalnogo universytetu - Scientific Bulletin of Uzhhorod National University, 28 (1). 108-114. Retrieved from: http://www.visnykeconom.uzhnu.uz.ua/archive/28_1_2019ua/20.pdf [in Ukrainian].

4. Zakon Ukrainy Pro banky i bankivsku diyalnist : vid 07.12.2000 № 2121-III. [The Law of Ukraine «About bank and banking» from 07.12.2000 № 2121-III] Retrieved from: https://zakon.rada.gov.ua/laws/show/2121-14\#Text [in Ukrainian].

5. Zakon Ukrainy Pro platizhni systemy ta perekaz koshtiv v Ukrayini vid 05.04.2001 № 2346-III. [The Law of Ukraine «About payment system and funds transfer in Ukraine» from 05.04.2001 \# 2346-III] Retrieved from: https://zakon.rada.gov.ua/laws/show/2346-14\#Text [in Ukrainian].

6. Ukrainski neobanky: klyuchovi gravci i potencijni nishi dlia rozvytku. [Ukrainian neobanks: key players and potencial niches for development]. Elektronna komerciya ta logistyka - E-commerce and logistics. 2021. Retrieved from: https://elnews.com.ua/uk/ukrayinski-neobanky-klyuchovi-gravci-j-potencijni-nishi-dlya-rozvytku/. [in Ukrainian].

7. Skilky neobankiv neobxidno Ukraini? [How many neo-banks does need Ukraine need?] Retrieved from: https://minfin.com.ua/ua/credits/articles/skolko-neobankov-nuzhno-ukraine/ [in Ukrainian].

8. Zakon Ukrainy «Pro finansovi poslugy ta regulyuvannya rynkiv finansovyx poslug» vid 12.07.2001 №2664III. [The Law of Ukraine «Of financial services and regulation of financial services markets from 12.07.2001 №2664III."] Retrieved from: https://zakon.rada.gov.ua/laws/show/2664-14\#Text [in Ukrainian].

9. Baxaryeva Ya.V. (2018). Mobilnyj banking yak perspektyvnyj napryam rozvytku bankivskyx informacijnyx system. [Mobile banking as a promising area of development of banking information systems]. Agrosvit - Agrosvit. Retrieved from: http://www.agrosvit.info/pdf/11_2018.pdf . [in Ukrainian]. 
10. Gorodyanska L.V. (2019). Osoblyvosti funkcionuvannya neobankiv.[Features of functioning of neobanks]. Finansovo-kredytni systemy $v$ umovax zminy dilovyx cykliv : mizhnarodna naukovo-praktychna Internet-konferentsiia., Kyiv, 15 travnya 2019 r. S. 141-143. [in Ukrainian].

11. Gut L.V. (2019). Neobanky: zarubizhnyj ta vitchyznyanyj dosvid funkcionuvannya. [Neobanks: foreign and domestic experience] Finansovo-kredytni systemy $v$ umovax zminy dilovyx cykliv : Mizhn. nauk.-prakt. Internet-konf -Financiak and credit systems in terms of changing business cycles The International Scientific and Practical Internet -Conference.(pp.143-145), Kyiv. [in Ukrainian].

12. Ozerchuk O.V. (2019). On-line banky: zarubizhnyj dosvid. [On-line banks: foreign experience] Finansovokredytni systemy $v$ umovax zminy dilovyx cykliv : Mizhn. nauk.-prakt. Internet-konf-Financiak and credit systems in terms of changing business cycles The International Scientific and Practical Internet -Conference.(pp.147-149), Kyiv. [in Ukrainian].

13. Gorodyanska L. V. (2019). Osoblyvosti funkcionuvannya neobankiv [Features of functioning of neobanks]. Finansovo-kredytni systemy $v$ umovax zminy dilovyx cykliv : Mizhn. nauk.-prakt. Internet-konf-Financiak and credit systems in terms of changing business cycles The International Scientific and Practical Internet -Conference.(pp.141143), Kyiv. [in Ukrainian].

14. TOP-10 neobankov v 2021 godu. [TOP-10 neobanks in 2021] Retrieved from: https://www.universepay.eu/ru/blog/top-10-neobankov-v-2021-godu [in Russian].

15. Oficijnyj sait Monobank - Website of Monobank. Retrieved from: https://www.monobank.ua/2020?lang=uk [in Ukrainian].

16. Oficijnyj sait Pryvatbank - Website of Privatbank. Retrieved from: https://privatbank.ua/about [in Ukrainian].

17. Oficijnyj sait PUMB - Website of PUMB. Retrieved from: https://www.pumb.ua/ [in Ukrainian].

18. Oficijnyj sait NBU - Website of NBU. Retrieved from: https://bank.gov.ua/ [in Ukrainian].

19. Oficijnyj sait Minfin - Website of Minfin. Retrieved from: https://minfin.com.ua/ua/banks/ [in Ukrainian].

20. Oficijnyj sait Kredobank - Website of Kredobank. Retrieved from: https://kredobank.com.ua/ [in Ukrainian].

21. Oficijnyj sait Ukrgazbank - Website of Ukrgazbank. Retrieved from: https://www.ukrgasbank.com/ [in Ukrainian].

22. Monobank stal tretym po kolychestvu kart, vperedy tolko — «PryvatBank» i «Oshhadbank» [Monobank became the third in terms of number of cards, ahead of only PrivatBank and Oschadbank]. Retrieved from: https://ain.ua/2020/10/02/monobank-stal-tretjim/ [in Russian].

23. Vorona. T., Dubilet D. (2020). Biznes na zdorovomu gluzdi. 50 idej, yak domogtysya svogo [Business on common sense. 50 ideas on how to achieve your goal]. Kyiv. Fors Ukraina. [in Ukrainian].

24. Matvijchuk N. M., Teslyuk S. A. (2021). Osnovni tendenciyi rozvytku bankivskyx innovacij v Ukrayini [Main trends in the development of banking innovations in Ukraine]. Ekonomichnyj chasopys Volynskogo nacionalnogo universytetu imeni Lesi Ukrayinky -Economic journal of Lesya Ukrainka Volyn National University. 1 (25), 2021. 79-87. Retrieved from: https://doi.org/10.29038/2411-4014-2021-01-79-87 [in Ukrainian].

Стаття надійшла до редакції 20.08.2021 р. 